\title{
E-learning Madrasah: Exploring Students and Teachers' Interactions to Support Literacy
}

\author{
Khairun Nisa ${ }^{1, *}$ Lolytasari Lolytasari ${ }^{2}$
}

\author{
${ }^{1}$ MAN 1 Tangerang Selatan, Tangerang Selatan, Indonesia \\ ${ }^{2}$ Tarbiya and Teaching Training, Syarif Hidayatullah State Islamic University, Jakarta, Indonesia \\ *Corresponding author.Email: nisadannovi@gmail.com
}

\begin{abstract}
The interaction must happen in online learning both synchronous and asynchronous. Without any interaction, there will be no learning experience. The interaction can happen between student and teacher, student and student, and student and content. The research aims to investigate the teacher and students' interaction in e-learning madrasah. The research method used Qualitative research, a case study at MAN 1 Tangerang Selatan (Islamic State Senior High School). The data were collected through the teacher's feedback, observation and questionnaire. The data analysis used qualitative data which analyzed the teacher and students' interaction in e-learning madrasah, observation, questionnaire and the students' learning outcomes. The research showed there was a lack of interaction between teacher and student in elearning madrasah with asynchronous. The interaction was limited to direct interaction in the form of discussions to support literacy. However, the students' learning outcomes obtained from the school report card were increased.
\end{abstract}

Keywords: Interaction, E-Learning madrasah, Learning outcomes, Literacy.

\section{INTRODUCTION}

Online learning has become common in today's world of education. Since the Pandemic of Covid 19 in early 2020 in Indonesia, all teachers and students have been forced to use an online learning system. Schools (teachers) and universities (lecturers) are obliged to teach and monitor the learning process using online/digital platforms or what is widely known as online learning or e-learning [1]. This causes some problems for the teacher and student who are not used to apply technology. Learning that was initially centered on the teacher as a source of learning has to become student-centered. Students are supposed to run on the websites and learning applications independently, so they will be able to learn the subject. The independence of students towards elearning is significant because active involvement of students in learning is an important part of achieving good e-learning [2]. While the teacher as a facilitator has to direct the students to learn by using websites and learning applications.

The use of Learning Management System (LMS) devices as software can allow students and teachers to carry out learning and teaching activities. One of the LMS is e-Learning Madrasah. E-learning madrasah is one platform that can be applied by the students to learn online both synchronously and asynchronously. This device was designed by the Directorate of Institutional and Student Facilities Curriculum, Ministry of Religion Affairs of the Republic of Indonesia with complete and easy-to-use features.

However, the use of e-learning madrasah becomes a scourge for teachers and students if the learning process occurs more often asynchronously. Students do not really understand the material being taught by the teacher if the teacher only gives the assignment. Particularly in learning English in which English is still as a Foreign Language (EFL) in Indonesia, the students will feel lost interaction if the teacher does not give any time to meet them even in a virtual meeting. They will feel frustrated and unmotivated to learn. The most obvious weakness of asynchronous online learning is the lack of direct interaction which causes learners to feel isolated. Therefore, the online teaching and learning activities must be synchronous and asynchronous. The synchronous will make the interaction between teacher and students; the asynchronous will increase students' participation in cognition [3].

Interaction is an essential factor towards e-learning goals realization which has three types; learner-content, 
learner-instructor and learner-learner [4]. Another study reveals that interaction is a meaningful way in EFL classrooms to create a relationship between teachers as a source of knowledge and students as a receiver to process the knowledge [5]. Hence it can be seen that studentteacher interaction is required in e-learning to achieve the learning goals. This study focuses on interaction of learner-instructor. Regarding this, the objective of research is to provide insights on the teacher and students' interaction which happen in e-learning madrasah with synchronous and asynchronous.

The interaction of synchronous learning arises at elearning madrasah while the teacher doing teaching through Video Conference. The students can ask the teacher directly related to the materials. They can also have the teacher's feedback face to face. Synchronous mediums of students and the teacher are present in the same setting just like traditional classrooms and this increases student-teacher interaction [6].

The interaction of asynchronous learning appears at e-learning madrasah when the teacher gives feedback in Timeline Kelas. Timeline Kelas is one feature of elearning madrasah which accommodates the teacher and students to do discussion. The teacher can post text, picture and link on it. The students can also comment on the teacher's posting and like the posting by giving thumb up. Nevertheless, the students do not seem enthusiastic to interact with the teacher. There is no transactional or interpersonal interaction. Lack of interaction between teachers and students can often hinder achievement of learning objectives [7].

\section{METHODS}

The method was Qualitative research using Case Study. The researcher investigated carefully a single-case study about the teacher and students' interaction in e- students were from the Social Science department who were taken with random sampling.

The data were collected from the teacher's and students' feedback in e-learning MAN 1 Tangerang Selatan, observation, and questionnaires. This data collection started at the beginning of e-learning madrasah using for about five months. The teacher at that moment tended to teach the students asynchronously rather than synchronously. Therefore, all the archival records in elearning madrasah were collected and analyzed including the teacher and students' interaction. There was observation data taken from pictures and observation sheets. The observation sheet was done by the researcher to get the triangulation data. There were also questionnaires which consisted of 15 structured questions related to the teacher and students' interaction in elearning madrasah to Support Literacy.

\section{RESULTS AND DISCUSSION}

The teacher's and students' interaction realizes critical learning and deeper exploration of knowledge [9]. Student teacher interaction in learning can provide high language and reasoning skills [10]. On the other hand, if there are two-ways of interaction between teacher and students, there will be learning outcomes. The learning outcomes are not only about the score, but also critical thinking skills. Critical thinking is the tool that helps individuals find answers or solutions to a person's confusions and problems [11].

The teacher must make some efforts to make the student interact in their learning activities. He cannot let the students only listen to the teacher's presentation. The teacher must make the students feel the teacher's presence by doing discussion forums. The teacher can make some questions that have to be answered by the students or ask the students to make some questions.

Table 1. The teacher's interaction

\begin{tabular}{|l|l|l|l|}
\hline No & Indicators & Respondents & Percentage \\
\hline 1 & The teacher motivates the students to do interaction in e-learning madrasah & 56 & $96 \%$ \\
\hline 2 & $\begin{array}{l}\text { The interaction between the teacher and the students in using e-Learning } \\
\text { Madrasah while they learned English. }\end{array}$ & 56 & 57,1 \\
\hline 3 & The teacher gives the feedback in e-learning madrasah & 56 & $96,4 \%$ \\
\hline
\end{tabular}

learning madrasah to support literacy. The research design included conducting a literature study, building theoretical framework, identifying research problems and sharpening research questions and selecting samples [8]. The respondents of the research were one English teacher who did online teaching using e-learning madrasah. Beside the teacher, there were 56 students from 113 students of eleventh grade of MAN 1 Tangerang Selatan who became the respondents of the research. The
Based on Table I, the result findings from the questionnaire showed that the teacher was 'the prompter'. He kept motivating the students to do interaction in Timeline Kelas. However, he asked the students to do the assignment or the test. He reminded them to open the Open Educational Resources (OER). Even though there was a small percentage of the interaction between the teacher and the students, the interaction was still happening. There are some reasons 
of this interaction to happen: (1) The student still answered the teacher's questions even they only answered short answer; (2) The students responded to the teacher's instruction by filling out the attendance, reading the lesson plan, downloading the OER and doing the assignment or Computer Based Test in e-learning madrasah.

The teacher sometimes provided his feedback in Bahan Ajar (Learning Materials). Bahan Ajar is one of the features of e-learning madrasah. It can be said as Open Educational Resources which allowed the students to retain, reuse, remix and redistribute. It can be e-book, videos, examples of assignments, etc. Giving feedback in a good question form helped students to think rationally [12]. Hence, the feedback must be dialogic, so the students can have meaningful learning.

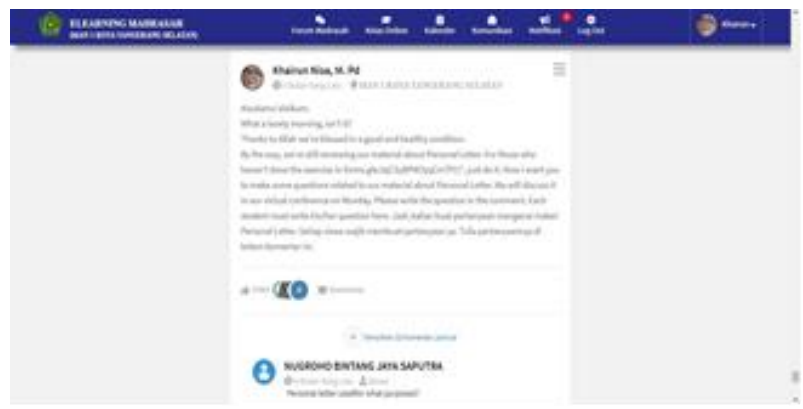

Figure 1 The display of teacher's interaction in asynchronous online learning by using e-learning madrasah.

Based on Figure 1, the teacher did not let the student get confused with the learning material and assignment. He instructed them to read the feedback if he cannot do synchronous online learning. This means the teacher did not only give the assignment but also, she gave the feedback. The teacher's interaction which is written in Timeline Kelas e-learning madrasah can be seen as follows:

“Assalamu'alaikum. What a lovely morning, isn't it? Thanks to Allah, we're blessed in a good and healthy condition. By the way, we're still reviewing our material about Personal Letter. For those who haven't done the exercise in forms.gle/zqCSyBPW3yqCm7P17, just do it. Now I want you to ask some questions related to our material about Personal Letter. We will discuss it in our virtual conference on Monday. Please write the question in the comment. Each student must write his/her question here..."

Table 2. The student's interaction
From the text above, the teacher embedded the students to have a religious character by praising AllahThe Almighty God. The teacher also acted as a facilitator who guided the students to do exercise. Moreover, he invited the students to ask some questions so the learning happened. There is evidence regarding the impact of teachers' questions on students' learning [13].

The teacher should make the discussion forum in order that there is an interaction between teacher and student [14]. The interaction is expected like dialog. Thus, the students were able to communicate particularly they could communicate in English both written and spoken. Obviously, e-learning madrasah has supported the student's interaction. There was a feature named 'Timeline Kelas' on it that could be used for the student to write something. The students could also give feedback or comment to the other student and to the teacher. However, the students' feedback was not graded. E-learning madrasah did not support the score for the students' response and comment. If there was a score in Timeline Kelas, the students certainly would be pushed to do the interaction. In MOODLE (Modular Object Oriented Dynamic Learning Environment)-one of the Learning Management System's features, there was a rating score for the discussion forum. This rating score could be used for the teacher to evaluate the students' answer. The discussion forum activity in this Moodlebased e-learning was able to increase student learning participation [15].

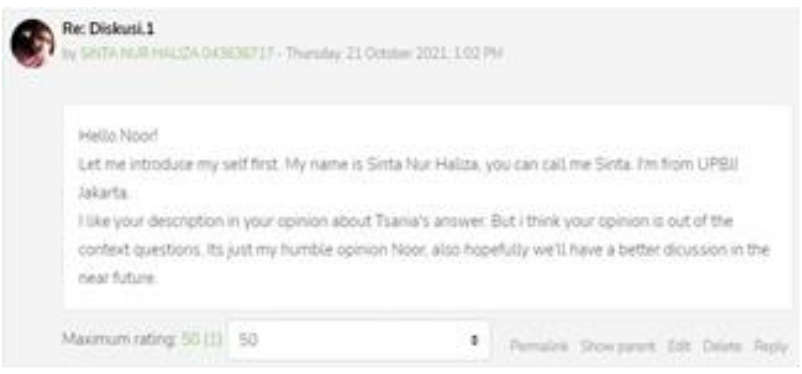

Figure 2 The display of student's interaction in asynchronous online learning by using MOODLE.

The student's interaction was needed to know how deep the students understand the learning material. The question was how the students wrote their opinion or respond to the teacher's instruction in e-learning madrasah. It was by reading their text in Timeline Kelas. the teacher could know whether the students were good language learners or bad language learners. It could be noticed from whether they communicated with their

\begin{tabular}{|l|l|l|l|}
\hline No & Indicators & Respondents & Percentage \\
\hline 1 & The students answer teacher's question e-learning in madrasah & 56 & $60,7 \%$ \\
\hline 2 & The students do not answer the teacher's question in e-learning madrasah & 56 & 39,3 \\
\hline
\end{tabular}


friends by using polite and well structured language or not. If they used polite language and the text was well structured, it means they were proficient language learners.

Table 2 showed that the students still responded to the teacher's interaction. Even though they only replied the teacher's question in Timeline Kelas with short answers, like 'Yes' or 'No'. It was about 39, 3 percent of the students who did not respond to the teacher's interaction. They did not want to write the comment or feedback in Timeline Kelas because they were afraid of making a mistake. They felt that their language structures were bad. Still, learning a language must be learning a mistake. If the students learned English by making a mistake, they would fix it. Hence, the teacher as a motivator had to encourage the students to learn English by mistake if they want to be good language learners.

Other findings revealed that the students preferred to ask some questions related to the material through WhatsApp. They did it since WhatsApp provided a personal chat, so they could feel the interaction more private. Social media, the fast triggering the means of virtual communication, internet-based technologies changed the life pattern of young youth [16]. It was different when they interacted by using Timeline Kelas which had no private chat. Therefore, the students felt shy to express their feelings toward their classmates. As a result, only a few students interacted with the teacher even if their respond was only 'Yes, Miss'. Beside the students did not interact with the teacher enthusiastically, they did not interact with other students. The teacher could not act as a facilitator who guided the students to do the interaction with other students. The teacher had to reinforce the students to express their ideas in the learning platform like e-learning madrasah. Mentoring activity was needed by teachers in understanding the use of the madrasah e-learning application and its application in the learning process during the COVID-19 pandemic [17].

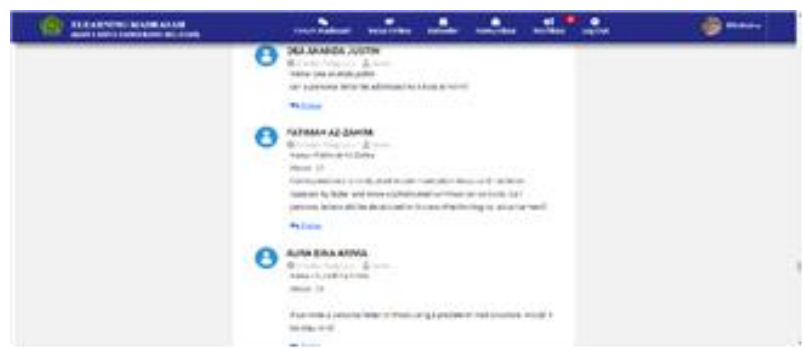

Figure 3 The display of student's interaction in asynchronous online learning by using e-learning madrasah.

Figure 3 displayed the students' interaction in asynchronous online learning by using e-learning madrasah. It can be inferred that the students still followed the discussion. They wrote some comments in English related to the material. For example, Fatimah- a student of eleventh grade social one wrote her comment in Timeline Kelas: "Correspondence is rarely used in communication because it has been replaced by faster and more sophisticated communication tools. Can personal letters still be developed in this era of technological advancement?" Based on this student's comment, the student's interaction happened because the student was given a chance to give her opinion by the teacher. The teacher also invited the students to give the question. It could be known that the student could express something by using English well.

Beside asynchronous online learning, the students also had synchronous online learning in English virtual classroom activities. However, the teacher used the Zoom application to do asynchronous online learning. There was a video conference menu in e-learning madrasah, but the teacher decided to use Zoom as a face-to-face virtual meeting (synchronous). The teacher used Zoom to minimize the connection problem. Some students could not connect to video conferences in e-learning madrasah because they had a problem with the connection. Furthermore, the students had already downloaded the Zoom application in their play store, so they could easily do the synchronous learning.

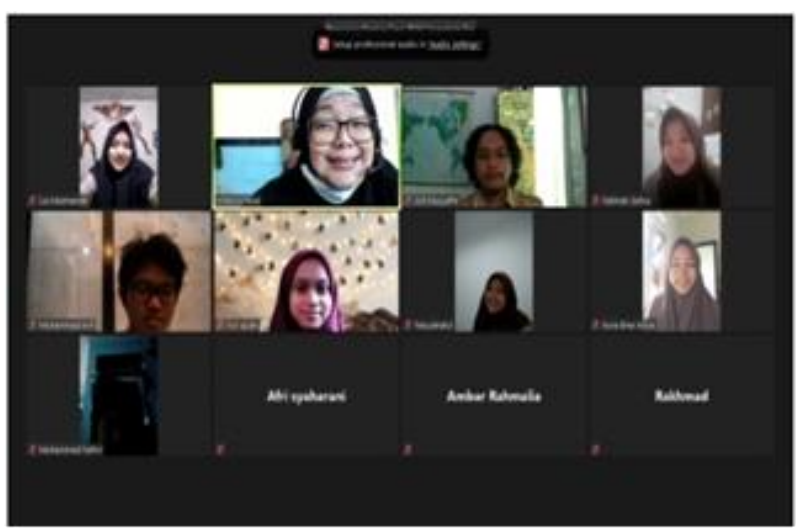

Figure 4 The display of the teacher and student interaction in synchronous online learning by using Zoom.

Figure 4 shows the interactions among students. The student could say and ask something to another student and teacher directly. They could feel the existence of their classmates and the teacher by seeing their gestures and expressions. However, some students did not turn on their cameras, so the teacher could not know the students' expressions while they communicate and interact in learning English. Because students did not turn on their video cameras during synchronous class meetings, the challenge was to see students during synchronous class meetings held via video conferencing software [18].

\section{CONCLUSION}

Based on the findings and discussions above, there is a teacher and students' interaction in e-learning madrasah 
to support literacy even though the interaction is mostly one-way interaction in asynchronous online learning. The teacher still does spoon feeding and the students are passive in doing interaction with the teacher. The teacher is the motivator, so he has to be able to motivate the students to do the interaction. He is supposed to provide dialogic feedback for the students in asynchronous learning. Moreover, he has to be creative to make the students interact. The interaction in e-learning madrasah to support literacy makes the students participate in learning. The students can have the learning experience in Timeline Kelas by doing forum discussion and reading the teacher's feedback in Bahan Ajar. Even the students are not engaged to do the interaction with the teacher, they still do the teacher's instruction which were provided in Timeline Kelas, like reading and downloading the OER, doing the assignment and Competence Based Test, and so on. As a result, the students' English achievement has improved from the odd semester to the even semester 79, 81>80, 86 .

\section{AUTHOR CONTRIBUTIONS}

All author conceived and designed this study. All author contributed to the process of revising the manuscript, and at the end all author has approved the final version of this manuscript.

\section{ACKNOWLEDGMENTS}

The researchers would like to praise Allah-The Most Beneficent and The Most Merciful. We also would like to convey our gratitude to the principal and students of MAN 1 Tangerang Selatan who have already permitted them to conduct the research

\section{REFERENCES}

[1] H.Mardiah, The Use of E-Learning to Teach English in the Time of the Covid-19 Pandemic, English Teaching and Linguistics Journal, 1(2) (2020) 4555.

[2] I. Abdurrahman, A. Suherman, Y. Sukrawan, A. A. Bandjar, The Level of Student Independence in Implementation of E-Learning-Based Leaning, Journal of Mechanical Engineering Education, 8(1) (2021) 128-139.

[3] T. Belawati, Pembelajaran Online, Tangerang Selatan: Universitas Terbuka, 2019.

[4] H. Firmansyah, F. Minandar, The Use of Madrasah E-Learning for Online Learning during the Covid19 Pandemic, Al-Ishlah Jurnal Pendidikan, 13(1) (2021) 530-542.

[5] A. Winanta, D. Rochsantiningsih, S. Supriyadi, Exploring EFL Classroom Interaction: An Analysis of Teacher Talk at Senior High School Level, ELS Journal on Interdisciplinary Studies in Humanities, 3(3) (2020) 328-343.

[6] M. Alhih, E. Ossiannilsson, M. Berigel, Levels of interaction provided by online distance education models, EURASIA Journal of Mathematics, Science and Technology Education, 13(6) (2017) 27332748.

[7] R.E. Putri, Model Interaksi Dalam E-Learning, Seminar Nasional Informatika (SEMNASIF), 1(1) (2013) 209-214.

[8] C. Merriam, Qualitative Research, A Guide to Design and Implementation. san Francisco: JosseyBass, 209AD.

[9] L. I. Mayasari, I. Kemal, The Role of Teachers in Implementing Distance Learning in the Middle of the Covid-19 Plague, Syst. Rev. Pharm, 11(12) (2020) 1553-1557.

[10] A. Gultom, Suhartini, Student Interaction, Teacher Competence, and Technology in Online Learning: Does it Create a Meaningful Learning?, Proceedings of the 6th International Seminar on Science Education, 2021, pp. 169-180.

[11] K. Changwong, A. Sukkamart, B. Sisan, Critical Thinking Skill Development: Analysis of a New Learning Management Model for Thai High Schools, Journal of International Studies, 11(2) (2018) 37-48

[12] Soh O-K, Ho Hong-Fa, Students Perceptions Toward the Use of Dialogig Feedback in Mobile Applications for Students Writing: A Case Study, Journal of e-Learning and Knowledge Society, 10(3) (2014) 37-49.

[13] M.Y. A.-Z. A. Al-Bargi, The Impact of Teacher Questioning on Creating Interaction in EFL: A Discourse Analysis, English Language Teaching, 10(6) (2017) 135-150.

[14] C. Riyana, Produksi Bahan Pembelajaran Berbasis Online, Tangerang Selatan: Universitas Terbuka, 2019.

[15] S. Fatmawati, Efektivitas Forum Diskusi Pada ELearning Berbasis Moodle Untuk Meningkatkan Partisipasi Belajar, Refleksi Edukatika: Jurnal Ilmiah Kependidikan, 9(2) (2019).

[16] J.A.N. Ansari, N.A. Khan, Exploring the role of social media in collaborative learning the new domain of learning, Smart Learning Environments, 7(1) (2020) 1-16.

[17] D. Riyan Rizaldi, A. Doyan, Z. Fatimah, M. Zaenudin, M. Zaini, Strategies to Improve Teacher 


\begin{abstract}
Ability in Using The Madrasah E-Learning Application During the COVID-19 Pandemic, International Journal of Engineering, Science and Information Technology, 1(2) (2021) 1-6.
\end{abstract}

[18] F.R. Castelli, M.A. Sarvary, Why students do not turn on their video cameras during online classes and an equitable and inclusive plan to encourage them to do so, Ecology and Evolution, 11(8) (2021) 3565-3576. 